\title{
FIRM GROWTH TYPES AND KEY MACROECONOMIC AGGREGATES THROUGH THE ECONOMIC CYCLE
}

\author{
Petra DOŠENOVIĆ BONČA ${ }^{1}$, Maks TAJNIKAR ${ }^{2}$, \\ Nina PONIKVAR ${ }^{3}$, Barbara MÖREC ${ }^{*}$ \\ 1, 2, 3Academic Unit for Economics, Faculty of Economics, University of Ljubljana, \\ Kardeljeva pl. 17, SI-1000 Ljubljana, Slovenia \\ ${ }^{4}$ Academic Unit for Accounting and Auditing and Academic Unit for Money and Finance, \\ Faculty of Economics, University of Ljubljana, Kardeljeva pl. 17, SI-1000 Ljubljana, Slovenia
}

Received 07 June 2017; accepted 27 December 2017

\begin{abstract}
The paper investigates the role and impact of different groups of firms according to their growth type on macroeconomic aggregates at various stages of the economic cycle based on the entire population of firms in Slovenia. The applied classification of growing and fast-growing firms is based on microeconomic theory. Results exhibit that despite larger year-to-year fluctuations, firms with growth towards their long-term equilibrium contributed most to macroeconomic aggregates, i.e. employment, capital and sales, especially in times of economic prosperity. Firms with growth that shifts them closer to their short-term equilibrium proved to be more important primarily for assuring employment stability. Furthermore, we show that using single growth measures prevents us from identifying all growing firms and capturing the true contribution of particular growth groups of firms to studied macroeconomic aggregates. The paper provides both theoretical and empirical information for managers for designing different types of firm growth and enables policy makers to adopt adequate industrial policy measures.
\end{abstract}

Keywords: Growing firms, fast-growing firms, growth types, macroeconomic aggregates, employment, investment, revenues, microeconomic theory of firm, economic cycles.

JEL Classification: D22, O12.

\section{Introduction}

This paper explores growing and fast-growing firms and particularly their type of growth during economic expansion and in periods of recession. We investigate the Slovenian economy in the 2007-2008 and 2010-2011 periods of positive economic growth and in 2009, 2012 and 2013 marked by economic crisis to show that different firm growth types prevail at various stages of the economic cycle. We explore how and to what extent firms with different

${ }^{\star}$ Corresponding author. E-mail: barbara.moerec@ef.uni-lj.si 
types of growth as initially proposed by Tajnikar et al. (2016) contribute to the creation of key macroeconomic aggregates through generating revenues, employment and investments at various stages of the economic cycle. In this way we show that the typology of different firm growth types according to microeconomic theory provides a deeper understanding of how different growing and fast-growing firms contribute to the creation of selected macroeconomic aggregates at different stages of the economic cycle. Using firms from Slovenia as the case is beneficial as data on the entire population of firms instead of sample or survey data is publicly available. Observing the entire population of firms in an economy with significant cyclical movements provides new insights into the impact of growing and fast-growing firms on macroeconomic aggregates. This is valuable for both managers and their shaping of firm growth strategies and also policy makers for implementation of adequate industrial policy.

In economic literature different theories of the firm exist and consequently also explanations of firm growth differ. The firm can be viewed as "production function" in neo-classical economics, as "strategic player" in new industrial organization economics, as "nexus of contracts" in agency theory, and as "governance structure" in transaction cost economics (Seth, Thomas 1994). As noted by Davidsson and Wiklund (2006), neither of these "theoretical firm" conceptualizations was created for the specific purpose of analysing firm growth. The analysis in this paper is based on microeconomic theory and thus the "production function" view.

We first allocate firms into six groups based on a set of different measures of growth and thereby build on the notion that "researchers should measure different forms of growth with different growth measures" (Delmar et al. 2003). The criteria for allocation of firms into groups is based on microeconomic theory and is also in line with existing measures of firm growth used in empirical studies, where employment and sales, but also wages and productivity are observed to study firm growth. As shown by the surveys of Henrekson and Johansson (2010) and Daunfeldt et al. (2014) all surveyed studies use employment and sales as growth indicators. Sales growth is the most common indicator used by managers and entrepreneurs (Coad, Hölzl 2012) and it is also often used in empirical studies on firm growth (De Jorge Moreno, Laborda Castillo 2011; Maçãs Nunes et al. 2012). Wages, productivity, revenue and value added are also used as growth variables (for example, Moreno, Casillas 2007; Hölzl 2009; López-Garcia, Puente 2012; Bjuggren et al. 2013; Hölzl, Frisenbichler 2010; Bravo-Biosca et al. 2013; Du, Temouri 2015).

However, instead of using a selected single measure of growth we apply a multidimensional measure of firm growth, in which we jointly use more indicators based on microeconomic theory to define six different firm growth types. Yet, our approach to expressing growth with multiple measures differs from other studies such as Delmar et al. (2003) who used 19 measures of firm growth over a 10-year period to identify seven different types of firm growth patterns using cluster analysis. We acknowledge that different types of growth have to be considered but based on microeconomic theory set a priori criteria for allocation of firms into distinct groups.

In line with microeconomic theory we view the firm as a combination of inputs (labour and capital) and outputs. As inputs and/or outputs change the firm grows. Both input and output changes are motivated by profit maximisation. Firm growth is thus the firms' 
transition from current position to its short-term or long-term equilibrium where firm attains its maximum profit. This transition is marked by altered quantities of inputs and outputs. Different types of firm growth can then be identified by the way the firm adjusts its inputs and outputs. This paper does not address characteristics or determinants of growth but uses a typology of growing firms to identify and categorize growing and fast-growing firms. Characteristics of high-growth firms have been investigated also for the case of Slovenia (e.g. Ruzzier, M., Ruzzier, M. K. 2015; Tajnikar et al. 2016) but this paper addresses precisely different types of growth and their contribution to macroeconomic aggregates.

The approach to investigating the impact of growing firms and their growth types at different stages of the economic cycle adopted in this paper contributes to existing empirical research. As shown by Moreno and Coad (2015), there are some consistent findings in the literature that reveal fast-growing firms are job creators and generally younger firms that can be found across all industries. The impact of growing and particularly fast-growing firms on employment has been widely investigated (e.g. Henrekson, Johansson 2010; Coad et al. 2014; Daunfeldt et al. 2014). We build on this tradition but extend the analysis to capture the magnitude of growing firms' impact not only on employment in Slovenia but also on revenue generation and investment. Given that these are important macroeconomic aggregates it is reasonable to assume that the impact of growing firms is dependent on the macroeconomic conditions. This is why we explore not only the impact of growing firms on macroeconomic aggregates but investigate the ways in which they generate them. We thus analyse which types of firm growth play a predominant role in creating key macroeconomic aggregates at various stages of the economic cycle.

\section{Typology of growing companies according to microeconomic theory}

We build on microeconomic theory and differentiate between short- and long-run firm equilibrium (e.g. Pindyck, Rubinfeld 2013) to define different types of growing and fast-growing firms. According to microeconomic theory, firms grow when their size changes due to adjustments in quantities of all production factors. Such changes correspond to the firm's path towards long-term equilibrium. In the short run, the firm can to some extent modify the scale of its activities but it cannot alter its size given the basic assumption that some production factors are fixed.

The described definition of firm growth enables us to define different conditions that emerge in firms and to use a specific typology of growing firms that divides them into six distinct groups shown in Figure 1. The illustration is for conditions of perfect competition but can be easily extended to conditions of imperfect competition. In this paper growth is defined as the firm's transition from its current position towards equilibrium which is the same both under conditions of perfect and imperfect competition (marginal revenues are equal to marginal cost). As in both cases the transition towards equilibrium is achieved by alterations of inputs and outputs, the following six types of growth are relevant both in circumstances of perfect and imperfect competition:

1. Firms with short-term growth based on improved capacity utilisation increase output or sales with the given quantity of labour and capital. Increased capacity utilisation 
lowers marginal and average costs thereby increasing output closer to levels associated with the short-run equilibrium (move towards point $A$ in Figure 1). In perfect competition the upper limit to growth is created by increasing short-run marginal costs while in imperfect competition also demand conditions (decreasing marginal revenues) play an important role.

2. Firms with short-term growth based on an increased quantity of labour achieve higher levels of output and profit by increasing labour while keeping capital fixed. This is a typical short-term adjustment of the firm. Also in this case the upper limit to firm growth is determined by increasing short-run marginal costs in case of perfect competition and demand conditions if imperfect competition is assumed (move towards point A in Figure 1).

3. Firms with short-term growth based on an increased quantity of capital also increase their output and profit (move towards point A in Figure 1) but do so by increasing the quantity of capital at a given quantity of labour. Increasing marginal cost and also decreasing marginal revenues represent the upper limit to growth depending on the prevailing market structure.

4. Firms with long-term growth are a textbook case of growing firms. Their output and profit increase in response to greater employment of both labour and capital. Larger output is thus a consequence of increased firm size and the firm's attempt to attain

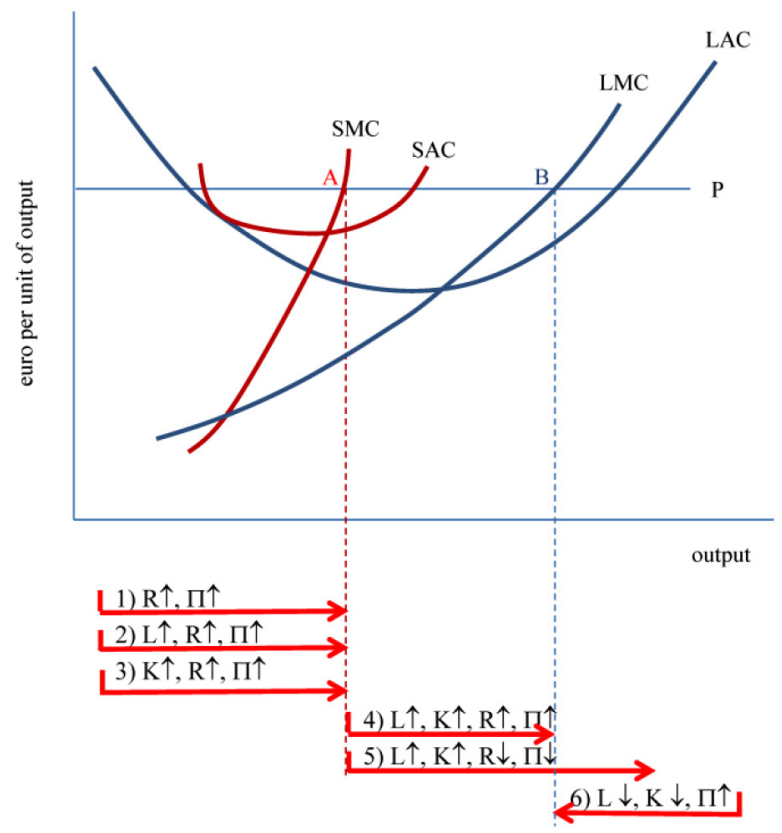

Note: P - price; SMC - short term marginal cost; LMC - long term marginal cost; SAC - short term average cost; LAC - long term average cost; increases or decreases of labour - L, capital - C, revenue $\mathrm{R}$ and profit $-\Pi$.

Figure 1. Types of growth according to the firm's adjustment to short- and long-run equilibrium 
its long-run equilibrium (move towards point B in Figure 1). Under conditions of perfect competition the upper limit to growth would be determined by diseconomies of scale while in imperfect competition also by limited demand.

5. Firms with unsuccessful growth also increase their size by enlarging quantities of both labour and capital in trying to achieve their long-run equilibrium (move towards point B in Figure 1). However, for these firms increased size does not lead to higher profit. Their capacity utilisation reduces and firm growth is unsuccessful. The firm has become too large given its economies of scale and/or demand conditions.

6. Downsizing firms are firms whose size exceeds their optimal size determined by profit maximisation. Such firms decrease their size but reductions of output are associated with increased profit. Such firms do not grow in terms of the quantity of employed inputs but in terms of their value for the owners and profit rates (move towards point B in Figure 1). Despite limitations of using annual profits to estimate firm value, we use increased profitability as an indicator of increased firm value. Most commonly such conditions develop in firms due to a decline in demand.

A combination of growth indicators is thus used to allocate firms into defined groups. The selection of indicators, however, still requires a decision on whether growth will be measured in absolute and/or relative terms (Delmar 2006; Coad, Hölzl 2012; Daunfeldt et al. 2014) given that this can lead to different results (see Almus 2002).

Regardless of the measure we use to capture firm growth, a zero growth rate of the selected indicator sets the boundary between non-growing and growing firms. Considering that only the latter group of firms creates economic growth, the distinction between nongrowing and growing firms is of particular importance.

A clear distinction between fast-growing and other firms growing at a slower pace is also needed to see if the impact on macroeconomic aggregates differs between fast-growing firms and other growing firms. Fast-growing firms have often been associated with the term gazelles. According to original definition, gazelles are firms whose sales have increased by at least 20 per cent per year over the interval and have base-year revenues exceeding USD 100,000 (Birch, Medoff 1994). A more common approach is to define fast-growing firms as a subgroup of upper 5 or 10 percent of growing firms given their growth over different periods (Henrekson, Johansson 2010). According to Brüderl and Preisendörfer (2000) and Almus (2002), fast-growing firms double their employment and create at least five additional jobs within 5 years. Acs (2011) uses the term "high-impact firms" for firms that have at least doubled their sales over a 4-year period and have an employment growth quantifier of two or more over the studied period. Based on Eurostat-OECD (2007) recommendations highgrowth firms should have at least ten employees in the start-year and annualised employment (or sales) growth exceeding 20 per cent during a 3-year period. By using such a definition, however, numerous firms are excluded from the analysis of the economic contribution of fast-growing firms and fast-growing firms are significantly larger and older (Daunfeldt et al. 2014). To identify fastest growing firms, the growth rate at a particular percentile of growth distributions can also be used (Bravo-Biosca et al. 2013).

This short review shows fast-growing firms are most often determined by observing the distribution of all growing firms and separating top-ranging firms from other investigated 
a)

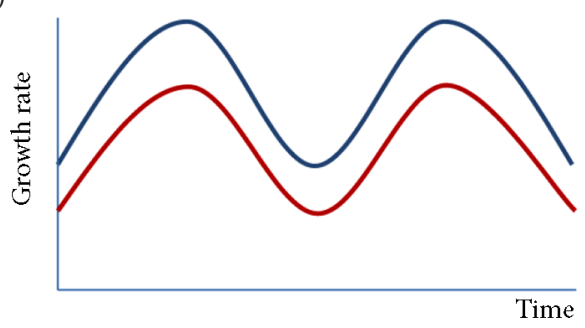

b)

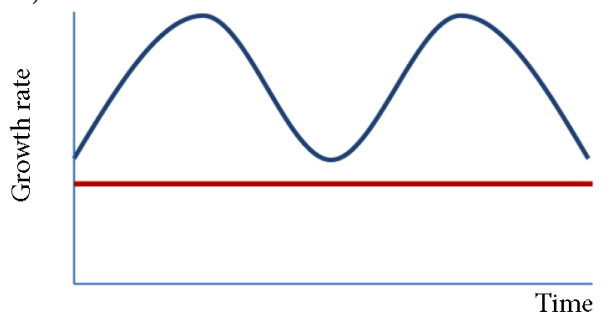

Note: red line-threshold separating fast growing firms from other growing firms; blue line-growth rate of fastest growing firms.

Figure 2. (a) Identification of fast-growing firms as a distinct upper share of all growing firms; (b) identification of fast-growing firms as those with growth exceeding a specified constant threshold

firms. Identifying fast-growing firms in this way is in principle tautological, since under such approaches every economy always has fast-growing firms and they always represents the same share of the total population of firms (see Figure 2(a)). In such a setting, stages of the economic cycle influence the identification of fast-growing firms and this violates the basic assumption that the characteristics of growing and fast-growing firms play a role in explaining cyclical economic fluctuations.

Given that we explore the impact of growing firms on key macroeconomic aggregates we identify fast-growing firms using the approach illustrated by Figure 2(b). Fast-growing firms are identified as firms with a growth rate above the set threshold value that is constant for the entire observed period. The threshold value of each observed variable is set at the 95th centile of the growth distribution which is observed throughout the whole studied period.

\section{Empirical analysis of types of firm growth}

We investigate the case of Slovenia, CEE member of the Eurozone, and use firm level financial statements' data from the Agency of the Republic of Slovenia for Public Legal Records and Related Services (APLR). All non-financial firms regardless of their legal form, size, or industry with the exception of individual private entrepreneurs (sole proprietors) are included in the database. Our analysis is thus based on financial data of the entire population of firms not in bankruptcy procedure (live unbalanced panel). The data set includes data for 2006, but the analysis of growth types refers to the 2007-2013 period, which enables us to capture both the periods of economic recession and revival. The average annual number of firms observed for the purpose of this paper in this 7-year period equals 55,606 firms. To take full advantage of using the rich dataset on the entire population of Slovenian firms instead of sample or survey data we avoid excluding micro and small firms from our analysis despite the challenges that resultantly emerge in our empirical analysis and are highlighted below.

\subsection{Allocation of firms into groups according to their type of growth}

Firms are first allocated to six different groups of growing firms following the typology discussed in Section 1 and based also on the criteria predominantly used in empirical studies 
(see the survey of Daunfeldt et al. 2014). We observe growth of labour (L) as an annual change of the number of employees, growth of capital $(K)$ in terms of the annual change in the nominal value of fixed assets (property, plant and equipment), growth of the volume of activity $(R)$ in terms of the annual change in nominal sales revenues, and growth of profit (П) in terms of the annual change in EBIT. Absolute measures of growth of listed variables are used and calculated based on non-deflated data given that we study the impact of growing firms on nominal annual macroeconomic aggregates.

The following criteria are used for allocating firms into distinct groups (see also Tajnikar et al. 2016):

- $\mathrm{L} \leq 0$ and $\mathrm{K} \leq 0$ and $\mathrm{R}>0$ for firms with short-term growth based on improved capacity utilisation $(\mathrm{G} 1)$;

- $\mathrm{L}>0$ and $\mathrm{K} \leq 0$ and $\mathrm{R}>0$ for firms with short-term growth based on labour (G2);

- $\mathrm{L} \leq 0$ and $\mathrm{K}>0$ and $\mathrm{R}>0$ for firms with short-term growth based on capital (G3);

- $\mathrm{L}>0$ and $\mathrm{K}>0$ and $\mathrm{R}>0$ for firms with long-term growth (G4);

- $\mathrm{L}>0$ and $\mathrm{K}>0$ and $\mathrm{R} \leq 0$ for firms with unsuccessful growth (G5);

- $\mathrm{L} \leq 0$ and $\mathrm{K} \leq 0$ and $\mathrm{R} \leq 0$ and $\Pi>0$ for downsizing firms (G6).

All other firms not satisfying the above criteria are allocated to the seventh group of non-growing firms.

Growing firms from G1 to G5 are then further divided into two subsets, i.e. fast-growing firms and other growing firms with lower growth rates. Also fast growing firms from individual groups of firms are attempting to attain either their short-run or their long-run equilibrium (points A and B in Figure 1) but at significantly higher growth rates than the entire population of growing firms. Fast-growing firms do not comprise the group of downsizing firms (G6).

Fast-growing firms are identified as firms with a growth rate above the set threshold value that is constant for the entire observed period (Figure 2(b)). Thresholds are determined separately for growth of employment, value of fixed assets and sales revenues given that they represent the criteria for our allocation of firms into growth groups. Each threshold is set by observing the distribution of annual growth rates of the underlying variable of studied firms for the 2007-2013 period and identifying the 95th centile of this distribution. The selected thresholds are thus the same regardless of the differences in economic conditions between studied years but the influence of cyclical economic movements is eliminated within the studied period only. The average annual number of fast-growing firms observed for the purpose of this paper in this 7-year period equals 9,966 firms. The threshold values are $44.47 \%$ for employment growth, $97.92 \%$ for fixed assets growth and $72.58 \%$ for sales revenues growth. High threshold values are explained by the size structure of the studied firms. Large and medium-sized firms represent only 2.7 percent of the pooled 2007-2013 dataset. A predominant share of small and micro firms thus strongly impacts the threshold.

\subsection{Prevailing growth types at different stages of the economic cycle}

As shown by Table 1, the share of firms allocated to one of the six groups of growing firms was expectedly largest in the 2007-2008 period of economic expansion and bottommost in 2009. Non-growing firms represented more than 46 per cent of all investigated firms in 
the 2009, when Slovenia's economy shrunk most notably. Also in the following years the dynamics of growing firms' (G1-G6) share corresponds to macroeconomic shifts with 2012 bringing another decline in economic growth and an increase in the share of non-growing firms following two years of weak economic recovery. Similar conclusions can be drawn for fast growing firms.

Most growing firms exhibited short-term growth based on improved capacity utilisation (G1) and their share fluctuated in line with GDP growth. Firms with short-term growth based on labour and capital (G2, G3) reacted to the crisis and adjusted the employment of their variable factor of production accordingly. In 2007-2008, firms with long-term growth (G4) were the second largest observed group, but regressed to only fourth position among the six groups following the 2009 crisis. The share of firms with unsuccessful growth (G5) remained bottommost in the entire analysed period. Their share did increase in 2009 but lowered again in the following years, indicating that during crisis firms became more cautious in making investment decisions. The share of downsizing firms (G6) shifted from the fifth position prior to the 2009 crisis to the second position thereafter. Fast-growing firms with increased capacity utilisation (FG1) similarly represent the largest share among fast-growing firms with dynamics closely following the fluctuations of GDP. The latter holds also for the share of firms from the group FG2, although its adjustment to cyclical movements was weaker. Firms with short term growth based on capital (FG3) and unsuccessful growth (FG5) represent only a small fraction among fast-growing firms. Since the 2009 crisis, the share of fast-growing firms with long-term growth (FG4) has declined most notably.

Table 1. Structure of firms according to growth type (source: authors' own computations based on the APLR data)

\begin{tabular}{|c|c|c|c|c|c|c|c|}
\hline \multicolumn{7}{|c|}{ Share (in \%) of companies by growth type } \\
\hline Year & 2007 & 2008 & 2009 & 2010 & 2011 & 2012 & 2013 \\
\hline G1 & 20.37 & 18.85 & 13.98 & 19.66 & 20.39 & 18.57 & 18.17 \\
\hline G2 & 12.82 & 12.28 & 9.43 & 10.80 & 10.81 & 9.50 & 11.58 \\
\hline G3 & 11.33 & 10.62 & 6.30 & 7.92 & 8.61 & 7.14 & 6.49 \\
\hline G4 & 15.78 & 14.99 & 8.43 & 9.11 & 8.97 & 8.12 & 8.91 \\
\hline G5 & 2.02 & 2.67 & 3.25 & 2.12 & 1.86 & 2.18 & 2.32 \\
\hline G6 & 9.94 & 9.58 & 12.58 & 13.57 & 13.68 & 15.36 & 14.29 \\
\hline Non-growing & 27.74 & 31.02 & 46.03 & 36.83 & 35.69 & 39.14 & 38.24 \\
\hline & Share (in \%) of fast-growing companies by growth type & \\
\hline Year & 2007 & 2008 & 2009 & 2010 & 2011 & 2012 & 2013 \\
\hline FG1 & 31.87 & 31.73 & 33.56 & 37.29 & 40.41 & 40.78 & 38.44 \\
\hline FG2 & 22.12 & 23.65 & 26.01 & 25.03 & 22.74 & 22.11 & 26.41 \\
\hline FG3 & 14.21 & 13.37 & 12.79 & 12.49 & 14.83 & 13.88 & 11.03 \\
\hline FG4 & 29.54 & 28.65 & 25.15 & 22.94 & 20.37 & 21.21 & 21.48 \\
\hline FG5 & 2.26 & 2.59 & 2.49 & 2.24 & 1.65 & 2.03 & 2.64 \\
\hline
\end{tabular}




\section{The impact of firms with different growth types on key macroeconomic aggregates in Slovenia}

In this section we observe the cumulative contribution of groups of growing and fast-growing firms to selected macroeconomic aggregates in the 2007-2013 period. Because individual groups of firms differ in the number of included firms and also due to our use of absolute measures of growth, we additionally use the Dunn (1964) nonparametric pairwise multiple comparisons to test whether the mean per-firm contribution to aggregates differs statistically significantly between different growth groups. We also analyse whether firms with different growth types impact selected aggregates differently during periods of economic expansion (2007-2008 of high growth and 2010-2011 with weak recovery) and decline (2009 with deep crisis and 2012 and 2013 with weaker economic downturn).

\subsection{Impact on employment}

The net cumulative 2007-2013 increase in the number of employees of all analysed firms that did not exit the market during the investigated period was 44,615 . While 99,761 jobs were lost in non-growing firms, all growing firms from groups G1-G6 together created 144,376 jobs with fast-growing firms contributing 110,907 new jobs, i.e. nearly 77 per cent. Only firms from three groups (G2, G4 and G5) contribute to increased employment according to the criteria set for allocating firms into growth groups. In the whole analysed period, most jobs $(161,791)$ were created by the group of firms with long-term growth G4 and firms with short-term growth based on labour from group G2 $(86,813)$. In groups of firms that pursue growth in other dimensions aside from labour (G1, G3 and G6), the biggest cumulative cut in employment amounting to 61.995 was in downsizing firms (G6).

Figure 3(a) and 3(b) show the year-on-year contributions of individual growth groups to aggregate employment. The average annual net increase in the number of employees from groups G1-G6 during years of economic prosperity (2007-2008 and 2010-2011) was 48

a)

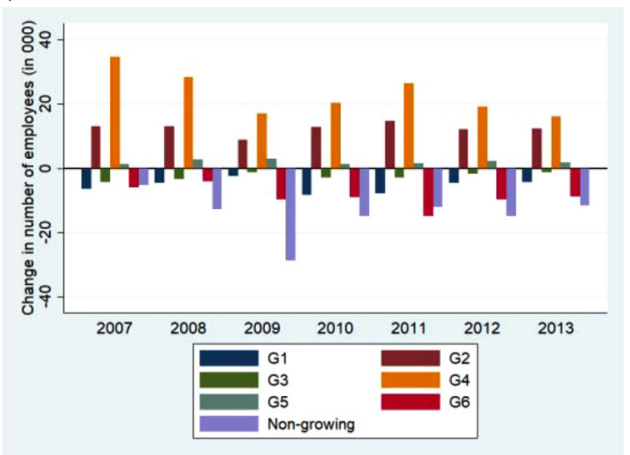

b)

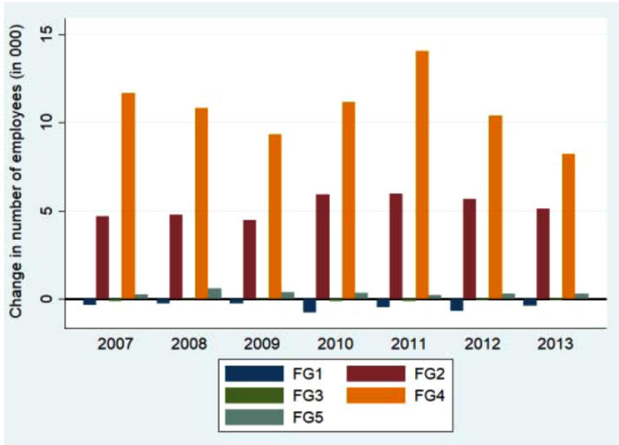

Figure 3. (a) Year-on-year change in the no. of employees by groups of growing firms (left); (b) yearon-year change in the no. of employees by groups of fast-growing firms (right) 
per cent above the average annual net increase of employees during crisis years of 2009 and 2012-2013. Given that individual groups represent an aggregate of a diverse array of firms, we use the Dunn test to investigate whether the mean per firm contribution to the aggregate employment differs statistically significantly between growth groups. All observed firms are first ranked according to their contribution to aggregate employment. The mean ranks of firms from all groups are then calculated. Dunn's test shows that the mean rank of firms with long-term growth (G4) is statistically significantly higher compared to mean rank of firms pursuing short-term growth based on labour (G2) throughout the whole analysed period thereby confirming the conclusions outlined in the first paragraph. Furthermore, the mean rank of non-growing firms (G7) is statistically significantly lower than the mean rank of firms from other groups that have negatively impacted employment (G1, G3 and G6) in all studied years. This holds true also for 2007 and 2011 when, as shown by Figure 3(a), the aggregate impact of downsizing firms was stronger. These results expectedly show that growing firms with short-term growth based on capital, improved capacity utilisation and downsizing have a weaker negative impact on employment compared to non-growing firms as defined in this paper. They also reveal an important advantage of the classification of growing firms used in this paper. Namely, by investigating the role of growing firms on job creation and using only employment as the growth indicator one underestimates both the population of growing firms and the stabilising role of firms that grow in ways other than additional employment of labour for aggregate employment dynamics.

As previously mentioned, cumulatively 110,907 new jobs were created by all fast-growing firms during the whole studied period. The average annual net increase in the number of employees of fast-growing firms during years of economic recovery was 20 per cent above the average annual net increase of employees in such firms during crisis years. More than 68 per cent of these new jobs were created by fast-growing firms with long-term growth (FG4) and about one-third by firms with short-term growth based on labour (FG2). Dunn's test confirms that in all years including the crisis periods the mean rank of firms with long-term fast growth remained statistically significantly higher than the mean rank of firms with short term growth based on labour. This implies that firms from FG4 are the most reliable source of job creation in all periods and macroeconomic conditions despite the fact that their contribution to aggregate employment is more prone to economic cycle swings compared to the G2 group (see Figure 3(b)).

\subsection{Impact on investments}

To study the contribution of particular growth types to aggregate investment, we observe fixed assets dynamics. The net cumulative 2007-2013 increase in the value of fixed assets of all analysed firms was EUR 8.7 billion. While the value declined cumulatively by EUR 563 million in non-growing firms, all growing firms from groups G1-G6 together created EUR 9.3 billion with fast-growing firms nearly 40 per cent. The average annual net increase in the value of fixed assets of growing firms (G1-G6) was 119 per cent larger in years with good macroeconomic conditions compared to crisis years.

As show by Figure 4(a), the group of growing firms with long-term growth (G4) contributed most to the annual increases of the value of fixed assets followed by the group of firms 
with short-term growth based on capital (G3) and firms with unsuccessful growth (G5). Dunn's test confirms that the average per firm investment of firms from G4 is higher compared all other groups throughout the analysed years at 5\% statistical significance. The only exception is the comparison of firms from G4 and G5 does not yield statistically significant differences. This result is not surprising considering that in our typology firms with unsuccessful growth are those that unsuccessfully pursued long-term growth. The analysis further reveals that the average annual aggregate increase in the value of fixed assets for group G4 almost halved in crisis periods compared to expansionary periods. Figure 4(a) further shows that the annual declines of the value of fixed assets were most notable for the group of firms with short-term growth based on improved capacity utilisation (G1), increased quantity of labour (G2) and downsizing firms (G6). Dunn's test reveals that while the aggregate disinvestment was largest for the group G1 in every analysed year, the mean rank of such firms is higher than the mean rank of firms from G2 at 5\% significance level throughout the analysed period. This indicates that the average per firm decrease in the value of fixed assets was larger in group G2. The group effect was larger for firms from G1 because the number of firms twice exceeded those from G2 (Table 1). Disinvestment of downsizing firms (G6) was least dependent on the economic cycle, as there was a negligibly small difference in the average annual decline of fixed assets in the crisis years compared to years of economic recovery. Dunn's test also confirms the average per firm disinvestment in this group was smaller compared to firms from G1 and G2 in all studied years. This suggests that most economic cycle related disinvestment can be attributed to firms from G1 and G2. This result supports our conclusion from Section 3.1 that measuring firm growth using single measures such as employment growth is not suitable given that it can neglect negative impacts of such growth on investment. By grouping firms as proposed in this paper one can separately observe those firms that add to employment and investment from those (e.g. from G2) that generate a trade-off to employment growth with a volatile negative impact on investment.

The investment activity of fast-growing firms (see Figure $4(\mathrm{~b})$ ) responded more intensively to macroeconomic shifts compared to growing firms, as the average annual net increase of fixed assets of all fast-growing firms was 78 per cent higher during years of economic

a)

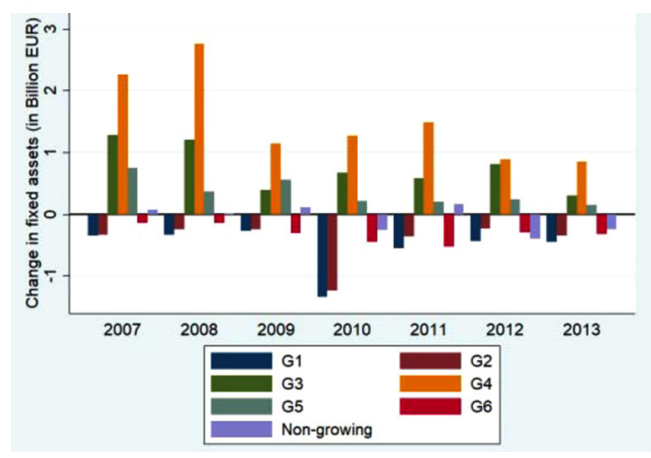

b)

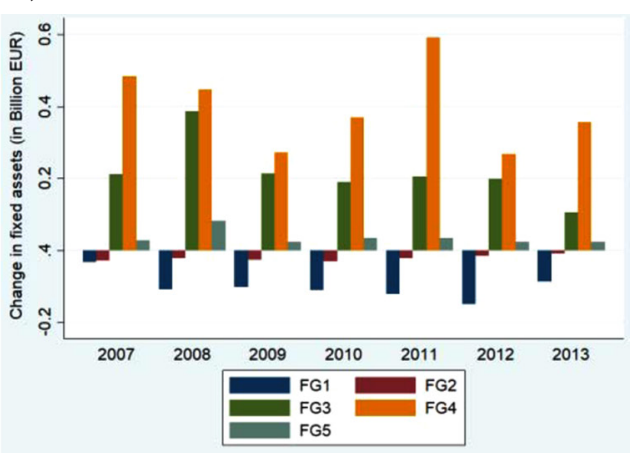

Figure 4. (a) Year-on-year change in the value of fixed assets by groups of growing firms (left); (b) year-on-year change in the value of fixed assets by fast growing firms (right) 
growth compared to crisis years. Fast-growing firms also played a weaker role in investment activities in the studied period compared to all growing firms as nearly 40 per cent of the total net increase in the value of fixed assets of growing firms (G1-G6) can be attributed to fast-growing firms (FG1-FG5), with the group marked by long-term growth (FG4) playing the most important role. Dunn's test also suggests an above average annual per firm increase in fixed assets for firms from FG4 in the 2007-2008 period of economic expansion. Since the 2009 crisis there are, however, no statistically significant differences in the ranking of firms from all the groups that contribute to increased fixed assets (FG3, FG4 and FG5). As shown by Figure 4(b), groups of firms with growth based on improved capacity utilisation (FG1) and an increased quantity of labour (FG2) contributed to disinvestment. Firms from FG1 also had the largest average annual reduction in the value of fixed assets and the Dunn's test reveals their mean rank is statistically significantly lower compared to all other groups of fast-growing firms in all analysed years.

\subsection{Impact on sales revenues}

The net cumulative 2007-2013 increase in sales revenues of all analysed firms was EUR 20.2 billion. While the value declined cumulatively by EUR 34.6 billion in non-growing firms, all growing firms from groups G1-G6 together created EUR 54.8 billion with fast-growing firms contributing almost 34 percent. The average annual net increase in the value of sales revenues of growing firms (G1-G6) was 151 per cent larger in years with good macroeconomic conditions compared to crisis years. In fast-growing firms the difference between the expansion and crisis periods was lower, i.e. 44 per cent.

As shown by Figure 5(a), the group of firms with long-term growth (G4) contributed most to the annual increases of sales revenues. Firms from G4 generated 53.8 per cent of the total cumulative revenue increase of all growing firms. Dunn's test shows that also the average per firm increase in sales revenues was highest for firms from G4 with statistically significantly results throughout the whole analysed period. Firms with short-term growth based on labour (G2) followed both in aggregate and per firm level. The aggregate contribution

a)

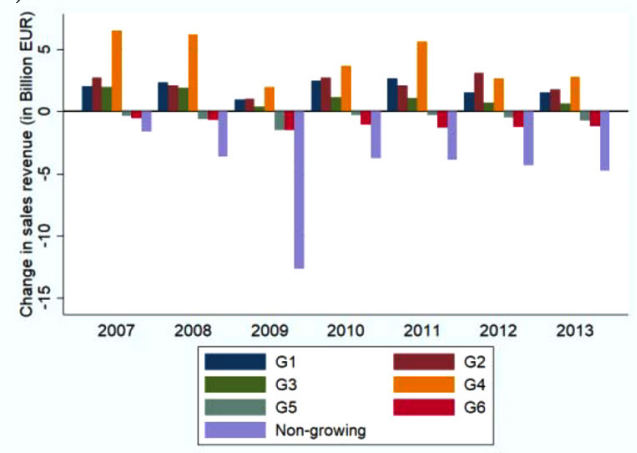

b)

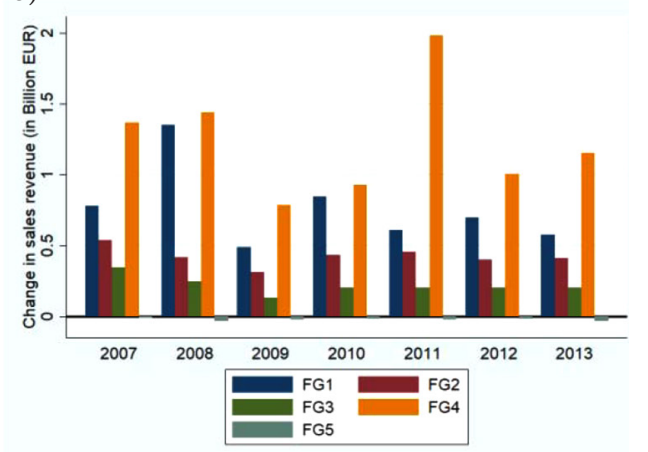

Figure 5. (a) Year-on-year change in sales revenues by groups of growing firms (left);

(b) year-on-year change in revenues by fast growing firms (right) 
to sales revenues of firms from G2 was, however, much less prone to macroeconomic cycle swings compared to group G4. The average annual increase in the value of sales revenues of firms from G2 was more than halved during crisis periods compared to years with favourable macroeconomic conditions.

Economic crisis, especially in 2009, had a strong negative impact on revenues of nongrowing firms. Revenues also declined in the group of downsizing firms (G6) that seem to have been able to reduce the amount of their production factors more than their revenues thereby increasing their profit levels. The group of firms that were most strongly affected by crisis are expectedly firms with unsuccessful growth G5. The average annual reduction of their sales revenues was 143 per cent higher during crisis periods compared to periods of economic expansion. This result highlights that measuring growth with single indicators such as growth of revenue doesn't capture firm with unsuccessful growth thereby ignoring important effects that are created when firms continue to employ labour and/or capital even though the market is no longer able to sustain this trend.

Fast-growing firms contributed nearly 34 per cent to the cumulative increase in sales of growing firms in the analysed period. As shown by Figure 5(b), firms from groups with shortterm growth based on increased capacity utilisation (FG1) and long-term growth (FG4) were the key contributors, contributing cumulatively 29.1 and 47.1 per cent to sales increases of growing firms, respectively. Dunn's test also confirms that the average per firm increase in sales was significantly higher for firms from FG4 compared to all other fast-growth types. Dunn's test further reveals that a notable share of FG1 in increased sales of fast-growing firms (cumulatively 29.1 per cent) is a result of a large number of firms and not a consequence of the above average per firm contribution to sales growth.

\section{Conclusions}

The use of the proposed typology of firm growth to explain how different growth types impact macroeconomic aggregates confirms the need for a theoretically consistent approach to firm growth which can be based on microeconomic theory. First, our analysis shows that identifying growing firms based on a single measure of growth prevents us from correctly identifying all growing firms and capturing the true contribution of particular growth groups of firms to studied macroeconomic aggregates. For example, using only employment as a growth indicator underestimates the population of growing firms and neglects the influence of other growing firms on the economy. Similarly, the classification of firms based on sales revenue growth doesn't capture firms with unsuccessful growth and their economic impact. Second, our analysis shows that the use of single growth indicators prevents the detection of opposing impacts of growing firms on macroeconomic aggregates. Employment growth can, for example, be negatively associated with investments growth or can be tied to positive investments growth. The use of the recommended typology remedies these shortcomings.

The analysis further shows some key characteristics of firm growth in Slovenia with some lessons that apply also to other countries:

1. Results show that growing firms adapt to crisis foremost by sales revenue, followed by investments and least by employment. Fast-growing firms react to economic cy- 
cles to a much lower extent with the strongest response in investments, less in sales revenue and - similarly to growing firms - least in employment;

2. Fast-growing firms are therefore especially important for employment, less so for investments, and lastly for sales revenue generation;

3. Both growing and fast-growing firms in transition to their long-term equilibrium are of key importance for all three studied macroeconomic aggregates. However, investments of growing firms are very sensitive to economic cyclicality, while employment and sales revenue are much more stable. Fast-growing firms with long-term growth are sensitive to cyclical oscillations when employing;

4. A notable impact on studied macroeconomic aggregates is characteristic also for firms shifting towards their short-term equilibrium with adjusting employment. Such firms have a weaker role for investments, while their sales revenue is subject to cyclical oscillations. Fast-growing firms with short-term growth based on labour are of key importance for employment thereby contributing to employment stability during economic cycles;

5. Firms with a key impact on investments are often unsuccessful in pursuing growth with their sales revenues being very cycle-dependent;

6. Downsizing firms have a negative impact on all studied macroeconomic aggregates including sales revenue, although they are exhibiting increasing profits.

Our results are relevant for managers as they point out that growth in any of the forms of transition to short-term equilibrium can last only a short period of time but can be very fast if it is based on employment and sales revenue growth. Managers can also use capacity utilization to adjust firm growth to economic cycles. However, while it is often important that both employment and sales revenue grow to maximize profit, in pursuing short-term equilibrium the growth of one input does not necessarily lead to the growth of others. Longterm profit maximization can be sustained over longer time periods given that all production factors can be adjusted. This conclusion applies to both growing and fast-growing firms. Transition towards long-term equilibrium is different from attaining short-term equilibrium and is less sensitive to economic cycles, except for investments. It is important to ensure that firms do not exceed their optimal size. If they do and market contracts, downsizing strategies should be implemented in such firms.

From the point of view of industrial policy we have to emphasize that accelerated employment or investment policies can achieve the growth of other aggregates, but this is not necessarily their result. Economic growth through increased firm size needs appropriate employment and investment policies but also measures that promote effective demand. However, it is of equal importance that legislation and economic policies also allow for strategies for reducing the firms' size. For economic policies determinants of firm growth are also important. This is why this paper encourages further investigation of characteristics and determinants of the six growth types analysed.

\section{Funding}

This work was supported by the Slovenian Research Agency [grant number P5-0117 (A)]. 


\section{Disclosure Statement}

The authors have no competing financial, professional, or personal interests from other parties.

\section{References}

Acs, Z. J. 2011. High-impact firms: gazelles revisited, Chapter 6, in M. Fritsch (Ed.). Handbook of research on entrepreneurship and regional development. Cheltenham: Edward Elgar, 133-174. https://doi.org/10.4337/9780857936493.00010

Almus, M. 2002. What characterizes a fast-growing firm?, Applied Economics 34(12): 1497-1508. https://doi.org/10.1080/00036840110105010

Birch, D. L.; Medoff, J. 1994. Gazelles, in L. C. Solmon, A. R. Levenson (Eds.). Labor, employment policy, and job creation. Boulder, CO: Westview Press, 159-168.

Bjuggren, C. M.; Daunfeldt, S. O.; Johansson, D. 2013. High-growth firms and family ownership, Journal of Small Business \& Entrepreneurship 26(4): 365-385. https://doi.org/10.1080/08276331.2013.821765

Bravo-Biosca, A.; Criscuolo, C.; Menon, C. 2013. What drives the dynamics of business growth?. OECD Science, Technology and Industry Policy Papers. No. 1. Paris: OECD Publishing. https://doi.org/10.1787/5k486qtttq46-en

Brüderl, J.; Preisendörfer, P. 2000. Fast-growing businesses: empirical evidence from a German study, International Journal of Sociology 30(3): 45-70. https://doi.org/10.1080/15579336.2000.11770218

Coad, A.; Daunfeldt, S. O.; Johansson, D.; Wennberg, K. 2014. Whom do high-growth firms hire?, Industrial and Corporate Change 23(1): 293-327. https://doi.org/10.1093/icc/dtt051

Coad, A.; Hölzl, W. 2012. Firm growth: empirical analysis. Chapter 24, in M. Dietrich, J. Krafft (Eds.). Handbook on the economics and theory of the firm. Northampton: E. Elgar, 324-338. https://doi.org/10.4337/9781781002407

Daunfeldt, S. O.; Elert, N.; Johansson, D. 2014. The economic contribution of high-growth firms: do policy implications depend on the choice of growth indicator?, Journal of Industry, Competition and Trade 14(3): 337-365. https://doi.org/10.1007/s10842-013-0168-7

Davidsson, P.; Wiklund, J. 2006. Conceptual and empirical challenges in the study of firm growth. Chapter 3, in P. Davidsson, F. Delmar, J. Wiklund (Eds.). Entrepreneurship and the growth of firms. Cheltenham, UK, Northampton, MA: E. Elgar, 39-61. https://doi.org/10.4337/9781781009949

De Jorge Moreno, J.; Laborda Castillo, L. 2011. Corporate growth, age and ownership structure: empirical evidence in Spanish firms, Journal of Business Economics and Management 12(1): 164-196. https://doi.org/10.3846/16111699.2011.555449

Delmar, F. 2006. Measuring growth: methodological considerations and empirical results. Chapter 4, in P. Davidsson, F. Delmar, J. Wiklund (Eds.). Entrepreneurship and the growth of firms. Cheltenham, UK, Northampton, MA: E. Elgar, 62-84. https://doi.org/10.4337/9781781009949

Delmar, F.; Davidsson, P.; Gartner, W. B. 2003. Arriving at the high-growth firm, Journal of Business Venturing 18(2): 189-216. https://doi.org/10.1016/S0883-9026\%2802\%2900080-0

Du, J.; Temouri, Y. 2015. High-growth firms and productivity: evidence from the United Kingdom, Small Business Economics 44(1): 123-143. https://doi.org/10.1007/s11187-014-9584-2

Dunn, O. J. 1964. Multiple comparisons using rank sums, Technometrics 6(3): 241-252. https://doi.org/10.1080/00401706.1964.10490181

Eurostat-OECD. 2007. Eurostat-OECD manual on business demography statistics. Luxembourg: Office for Official Publications of the European Communities.

Henrekson, M.; Johansson, D. 2010. Gazelles as job creators: a survey and interpretation of the evidence, Small Business Economics 35(2): 227-244. https://doi.org/10.1007/s11187-009-9172-z 
Hölzl, W. 2009. Is the R\&D behaviour of fast growing SMEs different? Evidence from CIS III data for 16 countries, Small Business Economics 33(1): 59-75. https://doi.org/10.1007/s11187-009-9182-x

Hölzl, W.; Friesenbichler, K. 2010. High-growth firms, innovation and the distance to the frontier, Economics Bulletin 30(2): 1016-1024.

López-Garcia, P.; Puente, S. 2012. What makes a high growth firm? A dynamic probit analysis using Spanish firm-level data, Small Business Economics 39(4): 1029-1041. https://doi.org/10.1007/s11187-011-9321-z

Maçãs Nunes, P.; Mendes, S.; Serrasqueiro, Z. 2012. SMEs' investment determinants: empirical evidence using quantile approach, Journal of Business Economics and Management 13(5): 866-894. https://doi.org/10.3846/16111699.2011.620172

Moreno, A. M.; Casillas, J. C. 2007. High-growth SMEs versus non-high-growth SMEs: a discriminant analysis, Entrepreneurship \& Regional Development 19(1): 69-88. https://doi.org/10.1080/08985620601002162

Moreno, F.; Coad, A. 2015. High-growth firms: stylized facts and conflicting results, in A. C. Corbett, J. A. Katz, A. Mckelvie (Eds.). Entrepreneurial growth: individual, firm, and region. Vol. 17. Bingley: Emerald Publishing, 187-230. https://doi.org/10.1108\%2FS1074-754020150000017016

Pindyck, R. S.; Rubinfeld, D. L. 2013. Microeconomics. $8^{\text {th }}$ ed. Boston: Pearson.

Ruzzier, M.; Ruzzier, M. K. 2015. On the relationship between firm size, resources, age at entry and internationalization: the case of Slovenian SMEs, Journal of Business Economics and Management 16(1): 52-73. https://doi.org/10.3846/16111699.2012.745812

Seth, A.; Thomas, H. 1994. Theories of the firm: implications for strategy research, Journal of Management Studies 3(2): 165-191. https://doi.org/10.1111/j.1467-6486.1994.tb00770.x

Tajnikar, M.; Ponikvar, N.; Došenović Bonča, P. 2016. Characteristics of firms with different types of growth: the case of Slovenia, Ekonomski anali 61(208): 27-47. https://doi.org/10.2298/EKA1608027T 